Mila N. Stričević Gladić

Univerzitet u Novom Sadu

Filozofski fakultet Novi Sad

milastricevic@ @otmail.com doi: 10.19090/zjik.2018.131-143

UDK 791.22:821.111(73).09

оригинални научни рад

\title{
SCREENING THE GOTHIC: PARODY OF THE GOTHIC GENRE IN TIM BURTON'S DARK SHADOWS
}

SUMMARY: Since the first Gothic work, Horace Walpole's The Castle of Otranto, was published in 1764, the Gothic genre has constantly been changing and evolving. One of its main purposes has always been social criticism, and therefore Gothic literature had to change together with the society. In the $20^{\text {th }}$ and especially in the $21^{\text {st }}$ century with the arrival of new technologies, Gothic moved from the paper to the screen. Film and television offered a whole new range of possibilities for the postmodern authors of Gothic works to express themselves. One such artist is certainly the American director Tim Burton who is famous for his dark comedies that are almost exclusively crammed with Gothic elements. In this paper, the author shows how, in his movie Dark Shadows from 2012, Tim Burton used parody as a tool to make an on-screen pastiche of Gothic elements packed in a dark comedy for the true lovers of the Gothic genre, creating a genuine example of the postmodern Gothic.

Key words: postmodern Gothic, parody, literature and film, Tim Burton, Dark Shadows

From the publication of Horace Walpole's The Castle of Otranto in 1764 until present day, Gothic genre and what is considered as Gothic has been constantly changing. In $18^{\text {th }}$ century, Gothic novels were dominated by the sense of horror. Exotic settings and gloomy castles where there was a villain lurking were an inevitable part of the Gothic works in the age of Enlightenment, The Castle of Otranto being a true representative of such works. In the Victorian age, the setting shifted from the exotic destinations to the cities, to the densely populated areas. This increased the feeling of terror that became dominant over horror. Gothic was no longer something that merely existed in the remote areas where harm could come only to those who seek it by desiring to explore unfamiliar places. In this era, apart from supernatural elements, the element of science is introduced. Scientists and

\footnotetext{
${ }^{1}$ Ovaj rad je proistekao iz seminarskog rada na temu „Gothic Elements and Parody in Tim Burton's Dark Shadows"

pisanog pod mentorstvom prof. dr. Ivane Đurić Paunović. Izlagan je na konferenciji Konteksti u decembru 2017. godine, ali nije poslat na recenziranje za zbornik radova te konferencije.
} 
alchemists who experiment with life became an important topic, a perfect example being Robert Louis Stevenson's Strange Case of Dr Jekyll and Mr Hide. Here, the Gothic moved to the inside of the human psyche. In the $20^{\text {th }}$ century, the genre evolved further and the elements of the Gothic genre became incorporated in many different genres, science fiction in particular. As Kamilla Elliot puts it, “'Gothic' no longer requires maidens imprisoned by tyrannical patriarchs in castle ruins, but becomes increasingly abstract, psychological, metaphorical and ideological..." (2007: 227). Gothic thus became an important part of the postmodern literature as well. Many postmodern authors used Gothic elements in their works, since this genre provided good grounds for planting and spreading postmodern ideas. For example, Otherness as an important term in postmodern literature is easily explored using the Gothic since vampires and other typical Gothic characters whose voice had not been heard before finally gain voice in the postmodern era. ${ }^{2}$

Postmodern Gothic, just like postmodernism in general, questions grand narratives, questions reality, creates hybrid forms. It also deals with binary oppositions such as reality and fiction, good and wrong or the centre and the margin. As Botting states,

Unstable, unfixed and ungrounded in any reality, truth or identity other than those that narratives provide, there emerges a threat of sublime excess, of a new darkness of multiple and labyrinthine narratives, in which human myths again dissolve, confronted by an uncanny force beyond its control (1996: 111).

Postmodern Gothic particularly undermines social conventions. From its very beginnings, the Gothic genre did not obey the social rules, and Gothic heroes and heroines were rebels in a way, but usually, in every Gothic piece of writing the social order eventually would not be changed. The evil Gothic force would permanently or temporarily vanish, and things would go back to the way they used to be. However, this social criticism is treated differently in postmodernism. Postmodern Gothic writers such as Angela Carter use parody to deconstruct traditional myths and recreate new ones. Parody is present not only in Gothic literature, but also in other media. It gradually became most dominant on the screen, with examples such as the television show The Adams Family or many movies

\footnotetext{
${ }^{2}$ This review is based on Botting's Gothic (1996) and Punter and Byron's The Gothic (2004).
} 
directed by Tim Burton. According to Elliot, "Gothic film parodies play with Gothic conventions..." (2007: 223). She also adds that "filmmakers and formal critics are primarily concerned with how Gothic film parodies parody Gothic film forms: sets, costumes, acting, cinematography, editing, special effects, sound and music" (2007: 224). Yet, these movies do not necessarily parody only "traditional" Gothic movies but also, as it is the case with Burton's works, they can parody traditional Gothic settings, characters and themes, and, additionally, use Gothic to parody certain social issues. An issue important for Burton's works is also that "Gothic film parodies undermine antipathy and resistance to patriarchy, while never ceding its power. Parodied patriarchs are comical, romantic, superannuated, entertaining, fallible, even loveable" (Elliott 2007: 225).

Parody, as Routledge Dictionary of Literary Terms defines it, is "one of the most calculated and analytic literary techniques: it searches out, by means of subversive mimicry, any weakness, pretension or lack of self-awareness in its original" (Childs and Fowler 2006: 166). In Burton's Dark Shadows for example, its goal is to subvert traditions and conventions. According to Linda Hutcheon, "parody is a perfect postmodern form, in some senses, for it paradoxically both incorporates and challenges that which it parodies" (1988: 11). Furthermore, through parody, myths are deconstructed and it allows for the new ones to be built, the ones that would fit the contemporary society. Hutcheon also argues that "parody appears to have become ... the mode of what I have called the "ex-centric," of those who are marginalized by a dominant ideology" (1988: 35). This blurring of the lines between the centre and the margin, and giving voice to the "ex-centrics", is frequently achieved through parody. Tim Burton frequently used parody in his works to this end.

From the $20^{\text {th }}$ century on, along with romance and other genres, Gothic moved to the screens. Gothic movies, and later horror movies, had an important role in spreading the ideas of the Gothic genre among the wider population. The mid to late $20^{\text {th }}$ century brought different screenings of gothic works, such as Mary Shelley's Frankenstein and Stoker's Dracula, but also new directorial accomplishments such as The Adams Family and many movies directed, written or produced by Tim Burton. He has directed and produced 27 movies so far and all of them feature a wide array of Gothic elements.

He has produced a body of work that focuses on the outcasts of society. His villains are rarely resolutely evil - they're normally misunderstood. 
Traditional narrative techniques exist in his films, but are secondary to image and feeling. (Le Blanc and Odell 2005: 11)

According to Le Blanc and Odell, subversion of the norm is one of the main characteristics of Burton's work. His characters include a man with scissors instead of hands who provokes compassion instead of fear (Edward Scissorhands), a family haunting ghosts instead of the other way around (Beetlejuice) and disturbingly likeable villains (Batman Returns). (9) They also note that in Burton's works, "the most sympathetically portrayed protagonists are those who differ from the norm - be they awkward, gauche, naive or simply misunderstood." (2005: 16) Such a character is definitely the protagonist of Dark Shadows. This movie is a remake of a TV series that aired in the 1970s. Here Burton includes different elements of the Gothic genre all of which he has used before, but this time he stirs them into a single movie. He plays with the traditional views of good and bad, with traditional Gothic settings and traditional Gothic creatures using parody to draw attention to different aspects of those Gothic elements. He also uses parody to subtly leave a social commentary on the modern day society.

\section{"Monsters"}

What is primarily important for the Gothic is the cultural work done by monsters. Through difference, whether in appearance or behaviour, monsters function to define and construct the politics of the 'normal'. Located at the margins of culture, they police the boundaries of the human, pointing to those lines that must not be crossed. (Punter and Byron 2004: 263)

The issue of what is normal and what not is one of the main topics of this movie. Tim Burton has already tried to completely eradicate those boundaries by combining supernatural creatures and human beings and heroes and villains as in the Batman trilogy to show that there are positive and negative characters in every "category". In his movies villains and freaks provoke sympathy, while "normal" people usually stay bland. Main characters in this movie are a vampire and a witch but the character list also includes other supernatural creatures and apparitions, such as werewolves and ghosts. Yet, it is impossible to classify all of these creatures as monsters, while some humans do deserve that title. Monsters here are outcasts, the Other, and throughout the movie they will desperately seek acceptance and happiness, just like Edward Scissorhands, another one of Burton's misfits. 
According to Punter and Byron "no other monster has endured, and proliferated, in quite the same way - or been made to bear such a weight of metaphor. Confounding all categories, the vampire is the ultimate embodiment of transgression..." (2004: 268). They cross the boundaries of life, ethics and morality. Vampires were present in folk literature of many peoples. When they became a part of Gothic literature and after Stoker's Dracula was published they started intriguing the readers even more. Yet, at the time they appeared, they were monsters. Dracula was, as Punter and Byron state, "the tyrannical aristocrat seeking to preserve the survival of his house" (2004: 269). Vampires were considered to be dangerous, bloodthirsty, cruel creatures. Yet, the end of $20^{\text {th }}$ century and $21^{\text {th }}$ century brought a whole new perception of vampires. They have been given voice, they have gained sympathy of the readers, they are no longer marginalized (Punter and Byron 2004: 270). In addition to that, "as well as becoming the subject rather than the object of the narrative, the modern vampire, rather than being solitary like Stoker's Count, desires companionship" (Punter and Byron 2004: 270). In the $21^{\text {st }}$ century, vampires have become the new Other. They were considered the ultimate evil for a long time, and now they are determined to show a different side of their story. Plenty of novels, stories, television series and movies have been made about vampires, about their place in the society and about their relationship with humans. In some of them, they are depicted as positive characters, sometimes they are still presented as villains, but most often, as is the case with the protagonist of this movie, lines are extremely blurred.

The main source of humour in Dark Shadows lies in the parody of a vampire through the character of Barnabas Collins. Mentally, he is stuck in the age in which he was cursed, dressed in a way one would imagine as something Dracula would wear and he speaks English with a strong British accent. This accent was a suggestion by Johnny Depp who played Barnabas in the movie. He "proposed that the vampire speak with a kind of Old World grandiloquence that would constantly be deflated by the blunt nonchalance of 1972 America" (Breznican 2012).

From his first appearance, he is a misfit. His cousin calls him "stiff, proper and old-fashioned" (Dark Shadows). Moreover, he is constantly discombobulated by his surroundings. He interprets the McDonald's sign as the sign of Mephistopheles, the Devil himself. He is bedazzled by the lights of the town, by traffic lights, television sets, gas stations and all of the new technology. He cannot understand how it is possible to have women doctors nowadays, or how his cousin Carolyn is fifteen years old and not married yet. How much of an outcast he is becomes most 
obvious when he is contrasted with Carolyn, who is a teenager and a representative of the new age. She is shocked by his behaviour and asks him: "Are you stoned or something?" to what his answer is: "They tried stoning me, my dear, it did not work", obviously ignorant of the meaning of her question. This humorous effect that he provokes once he finds himself free again after two hundred years also tells a lot about how times change and how something that once was normal is now unacceptable.

Barnabas provokes fear and disgust while also provoking sympathy and compassion. He is not a vampire willingly and he cannot resist his urges. Viewed from the point of psychoanalytical criticism, it may be said that the "vampirical" part of him is his id, something he has no control over. At the same time, his ego suffers while his superego tries to overcome his differences and fit into the society. In fond, he is kind and loving, protective towards women and towards his family, which are not characteristics that would normally be ascribed to a vampire. He is a creature that people would fear without even getting to know him, he is the Other. Yet, his family eventually accepts him, protects him and he even manages to rediscover his true love. Hence, by parodying the traditional characteristics of a vampire, Burton is trying to show that not everything that is different is dangerous, but also that it might be. Barnabas cannot resist his urges and he is a murderer, even though he would never harm his family and the people he loves. This ambivalence is one of the important characteristics of Gothic genre, since, even though Barnabas represents a parody of the vampires from the periods of early Gothic, he is still not much different from Dracula. He too cannot resist his urges, and at the same time he tries to preserve and protect what is his at any cost. This issue is present in Burton's earlier works as well. According to Ryan Weldon, "Burton examines the attempt to act authentically in a world in which his characters seem to have no place and no recourse to the roles legitimized by society and the power inherent in that legitimacy." (2014: 31) His vampire protagonist is not the Other just because he is a vampire. Through parody, he is perceived as more human. By parodying "typical" vampirical behaviour, Burton places his protagonist Barnabas on the very margin of existence. He is not human, but he is not really a vampire either. Eventually, he is accepted for who he is, regardless of the etiquette.

The antagonist in this movie is a witch, Angelique. She is the servant of the Collins family, but after Barnabas rejects her, she swears to destroy the entire family, and she eventually succeeds in replacing them as the most important person in town. She reincarnates over and over again, establishing herself as a powerful 
business woman. People respect, trust and obey her. They would hunt down whomever she points her finger at, which is opposite to what used to happen to the women who were accused of being witches - here, this role as well is reversed - the witch strikes back. From the point of view of feminist literary criticism, she is a woman who stood up for herself, reversed gender roles, climbed the social ladder and gained power. Yet, there is a bitter commentary to this. Similar character in one of Barton's previous works is Selina, the Catwoman from Batman returns (2002). In the beginning, Selina is also unnoticeable and inauthentic, looked down on by people in power. Even though the two heroines are similar in the beginning, Burton gave Angelique more agency, since she takes her life into her own hands and stands up for herself, as opposed to Selina, whose change is more passive. Nevertheless, Angelique is still not satisfied. She is lonely because all she actually needs is a companion. She remains a misfit, since, although she achieves her goal to climb the social ladder, she does not manage to find someone who would love her and who could understand her true nature and someone whom she might spend the eternity with.

On her journey toward becoming an authentic subject, how closely her identity performance matches the expectations of any outside observer does not apparently concern her. Instead, she continually seeks legitimacy and justification according to her own awareness of the situation at hand. (Weldon 45)

Weldon used these words to refer to Catwoman, however, they can be perfectly applied to Angelique as well.

Apart from Barnabas and Angelique, other supernatural creatures in the novel are there to add up to the Gothic atmosphere of the movie or for the purposes of parody. Ghosts, for example, were always considered both terror and horror provoking. In this movie, ghosts can be seen only by certain people, and they are benevolent. Ghosts serve to represent the past intrusion in the present, also something characteristic for the Gothic genre. In the Victorian age, the supernatural of the $18^{\text {th }}$ century was replaced by science, so lunatics, strange scientists and doctors move centre stage. In this movie, the supernatural and science stand side by side. The boy, David, can see ghosts but nobody believes him, hence the family hires a psychiatrist, Dr Hoffman, to treat him. Yet, Dr Hoffman's qualifications are very questionable, since she is obviously an alcoholic. She will, upon hypnotizing Barnabas and discovering that he is a vampire, try to turn herself into one just to 
prevent herself from aging and growing old, by using transfusions with Barnabas' blood. As opposed to other scientists who experimented with some higher purpose, whether good or bad, she is driven by a superficial wish to remain young and beautiful. There is also the werewolf, a horrible magical creature. Its appearance was an unexpected plot-twist, since the young teenage girl who from the very beginning was odd, grumpy, uninterested and even violent sometimes eventually turned out to be a werewolf asking her family "not [to] make a big deal out of it" (Dark Shadows). This is in a way a parody of all teenage children who misbehave, but also a sort of an excuse for them, since being a teenager, just like being a werewolf, is something that cannot be changed, one can just wait for the critical period to pass.

\section{SETTING AND ATMOSPHERE}

The most Gothic thing in this movie in the traditional sense of the word is certainly the setting. Setting is also something typically "Burtonesque". As Botting claims: "Gothic atmospheres - gloomy and mysterious - have repeatedly signalled the disturbing return of pasts upon presents and evoked emotions of terror and laughter" (1996: 1). In this movie, the atmosphere signals precisely that - the intrusion of the past in the present life of the characters. From the first scene, the atmosphere of gloom is present - foggy darkness is the prevailing image. This setting from the very beginning hints that the story that is about to develop is going to have elements of Gothic.

Castles were most often the settings of the early Gothic works. Later on, they were replaced by old houses. The Gothic mansion in this movie lies somewhere in-between - it resembles a castle, but it is actually a home of a wealthy family built in 1760. The mansion goes through many transformations throughout the movie. When Victoria arrives, it is an abandoned house that was left to decay due to the lack of both money and enthusiasm of its owners. It is grey, dusty and represents a true Gothic setting. When Barnabas returns, he provides the money and the house is once again a warm, comfortable home. Finally, at the end of the movie, the house is destroyed in the combat between the Collins family and Angelique. These transformations of the house follow the development of the plot. The house is a symbol of the initial division that existed between the noble Collins family and their servants which led to the main conflict in the first place. In order for the conflict to be resolved, the house needs to be destroyed. 
Even though it is "decaying, bleak and full of hidden passageways" (1996: 2), which is how Botting describes castles that represent a Gothic setting, what makes this mansion different from other Gothic settings is that the people who live in it do not consider it scary. It parodies Gothic mansions in several ways. Firstly, the secret doors and passages in this house often turn out to be not so secret, but rather places where things like badminton equipment and handwork are kept. Secondly, it is a haunted house, yet nobody fears the ghost but proclaims the boy who says that he sees it to be a loony. It is a house in which a vampire, a werewolf and ghosts live side by side with "normal" people, yet the question who is normal is really problematic there. There is no horror in the eyes of the characters; they are not being chased by evil forces. Thirdly, the house does not fit in the age of 1972, since it looks exactly the same as it did when it was built in 1760, with small changes in the form of electricity, television and alike. The house is a misfit, just like its owner, Barnabas. The condition of the house indicates that the Collins family has been living in the past, and constantly dwelling upon their glorious past days when they were rich and influential. Not until the house is gone, will the family be able to move on.

Apart from the house, another Gothic setting is the forest. The forest through which women pass in order to get to Widow's Hill is a dark and gloomy place that has a sense of evil pinned to it. The forest is also a place where vampires get up from their graves, yet in the scene when Barnabas is released, this forest is at first represented as a gloomy place, but then, when through trees Barnabas sees the lights of a car, this atmosphere is broken by the humorous effect of Barnabas' encounter with the lights which he thinks belong to the devil: "Show yourself Satan, mock me not with your strange luminance!" (Dark Shadows) From that moment on, the setting in which Barnabas finds himself is no longer Gothic, but rather comical.

In this movie, the goal of the setting is to change the atmosphere between scary and dark to humorous. Setting constantly changes as the story develops. One house is a lovely family home one moment, and a horrifying Gothic mansion the other. Through combining traditional Gothic elements and parody of the same, Burton showed how it is impossible to draw sharp lines between what is Gothic and what is not, and also between what is good and what is wrong. 


\section{SOCIAL COMMENTARY}

Tim Burton said that he intended the movie to be "a mixture of things you know - melodrama, emotion, humour, light and dark mixed together" (Pilkington 2012). He knew that this combination might not give positive results and he did not know how the audience would react. However, through this mixture of things familiar to the viewer, he intended to draw attention to the outcasts he himself once belonged to. This movie shares many themes that are characteristic for the Gothic genre, and many of them are represented through parody.

Gothic genre has always been concerned with the social issues. This movie begins in the year of 1760, the age in which the Americas were settled by Europeans in search for a better, more prosperous life. This movie showed how it was possible for people from Britain to go to USA, build an entire town and live like royalty. 1760s were also an era preceding the revolution and formation of an independent country. It was the age where people fought for goals higher than themselves. Yet, that social order collapses under Gothic elements in the movie. The appearance of a witch brings dark and gloomy atmosphere that eventually causes the demise of the upper class embodied in the Collins family and allows the woman who was once a servant to become the most influential person in the town. Here the authors of the movie may also be alluding to the American dream, where everything is possible if you are able enough. It can even be said that this is a parody of the early Gothic genre that claimed to be against the social order but actually supported it, by not changing anything. The order always used to be re-established. Here, the witch does manage to crash the social order. However, it is questionable whether she changed it for better or for worse, and even whether she truly changed anything except for the person on top of the social ladder.

The age in which the main plot of the movie is set also plays an important role. Apart from the fact that the original series Dark Shadows was aired at that time, Tim Burton said that they chose the Nixon Era for cultural reasons. They placed the plot in 1972 because they wanted to contrast Barnabas Collins who is ready to sacrifice himself for his family and his family is ready to do the same for him with the era in which people were concerned only with their own wellbeing (Breznican 2012). The seventies represent a post-industrial, or cultural and literary terms, postmodern era. There is a lot of comical social commentary in the movie. For instance, when the matriarch of the house, Elizabeth Collins, interviews Victoria for 
the governess position, she asks her three questions, and after Victoria answers them, she is given the job:

Elizabeth: "How do you feel about the president?"

Victoria: "Never met him."

Elizabeth: "The war?"

Victoria: "I don't watch television."

Elizabeth: "Do you think the sexes should be equal?"

Victoria: "Heavens no, men would become unmanageable" (Dark Shadows)

These answers represent a subtle parody of both the politics and feminism. The Collins family and their home represent a metaphor for the American society of the time. According to Professor Will Kaufman,

President Nixon's decision in August 1971 to uncouple the dollar from the gold standard, allowing its value to float freely against that of other currencies, resulted in wild global currency fluctuations. This, combined with a surge in domestic borrowing, marked a decline in American manufacturing, and global crop shortages resulted in mid-decade economic stagnation and lengthening unemployment lines. At the same time, rocketing prices - inflation - combined with joblessness to produce an economic scenario never before seen in America." (12)

They are all unemployed; they survive on the breadcrumbs of their previous fortune, awaiting someone to resolve their situation. This may be a criticism of a somewhat spoiled American society used to living a prosperous life.

\section{CONCLUSION}

Tim Burton as a director has a recognizable artistic style. Macabre, weird and eccentric lie in the heart of all his works. All of his movies have elements of the Gothic genre, postmodern gothic in particular. This also means that Burton turns to parody in many of his works. Parody as a device allows Burton to explore issues of identity and social norms. Humour is often used as a defence mechanism when dealing with something serious or painful. Burton uses humour to appeal to his viewers' emotions. It is not easily explained why one likes his character of Barnabas 
Collins. By parodying a typical vampire, Burton humanizes him and makes him likeable.

Parody of the setting also serves an important role - to constantly change the atmosphere in the movie. Seemingly serious, dark and gloomy, Gothic scene is usually interrupted by a comical situation stemming from parodying certain Gothic elements. This can be seen as some kind of a comic relief, but usually those comical interruptions also parody a certain social or individual behaviour or situation.

To sum up, the movie Dark Shadows is above all a parody of a vampire as a creature from Gothic fiction, but it is much more than that. It is a parody of the entire history of the Gothic genre. It is a pastiche of Gothic elements characteristic for early Gothic, Victorian Gothic and postmodern Gothic. According to Botting, "the play of fear and laughter has been inscribed in Gothic texts since their inception, an ambivalence that disturbs critical categories that evaluate their seriousness or triviality" (1996: 109). This movie constantly plays with fear and laughter, and through dark comedy draws attention to certain cultural issues such as the line between good and evil, right and wrong, normal and monstrous. It shows how easy it is to put people in boxes, but also how impossible that is. It also deals with social order and with what is accepted in a society, like many other Gothic works. As Breznican puts it, this story is "heart-warming and bloodcurdling at the same time" (2012). The protagonist is at the same time a hero and a victim and a villain, as it is often the case in real life. Lines are almost always blurred. Finally, even though a lot of traditional Gothic elements were deconstructed by means of parody, they were reconstructed afterwards in order to give the voice and the happy ending to the Other.

\section{REFERENCES}

Botting, Fred. 1996. Gothic. London: Routledge.

Breznican, Anthony. 2012. "INTO THE SHADOWS. (Cover Story)." Entertainment Weekly 1206:30-36.

http://search.ebscohost.com/login.aspx?direct=true \&db=a9h\&AN=7505388 $6 \&$ site $=$ ehost-live (25 June 2015)

Childs, Peter, and Roger Fowler. 2006. The Routledge Dictionary of Literary Terms. London: Routledge.

Dark Shadows. 2012. Warner Home Video. Film. 
Elliott, Kamilla. 2007. "Gothic - Film - Parody." The Routledge Companion to Gothic. Ed.

Catherine Spooner and Emma McEvoy. London: Routledge.

Hutcheon, Linda. 1988. A Poetics of Postmodernism: History, Theory, Fiction. London: Routledge.

Kaufman, Will. 2009. American Culture in the 1970s. Edinburgh: Edinburgh University Press.

Odell, Collin, and Michelle Le Blanc. 2005. Herts: Pocket Essentials.

Pilkington, Mark. 2012. "Camp Collinwood." Film Journal International 115.5: 14. http://search.ebscohost.com/login.aspx?direct=true \&db=f5h\&AN=7474180 $1 \&$ site=ehost-live_(25 June 2015)

Punter, David, and Glennis Byron. 2004. The Gothic. Malden, MA: Blackwell Pub. Weldon, Ryan. 2014. "Catwoman and Subjectivity: Constructions of Identity and Power in Tim Burton's Batman Returns." The Philosophy of Tim Burton. 31-46. Kentucky: The University Press of Kentucky

Mila Stričević Gladić

GOTIKA NA EKRANU: PARODIJA GOTSKOG ŽANRA U FILMU „TAMNE SENKE” TIMA BARTONA

\section{Rezime}

Otkako je objavljeno prvo gotsko književno delo Otrantski zamak Horasa Volpola 1746. godine, gotski žanr se neprekidno menjao i razvijao. Kako je jedan od glavnih ciljeva ove književnosti uvek bila društvena kritika, gotski žanr je morao da se menja zajedno sa društvom. U dvadesetom, a posebno u dvadesetprvom veku, sa dolaskom novih tehnologija, gotika se preselila sa papira na ekran. Film i televizija pružili su postmodernističkim autorima gotskih dela sijaset novih mogućnosti da se iskažu. Jedan od takvih umetnika je svakako američki režiser Tim Barton, poznat upravo po svom mračnim komedijama koje su skoro bez izuzetka pune elemenata gotskog žanra. U ovom radu, autor pokazuje kako je u svom filmu Tamne senke iz 2012. godine Tim Barton koristio parodiju da bi stvorio ekranizovani pastiš gotskih elemenata upakovan u mračnu komediju za prave ljubitelje gotskog žanra i time stvorio istinski primer postmodernog gotskog dela.

Ključne reči: postmoderna gotika; parodija; književnost i film; Tim Barton; Tamne senke 
